\title{
Movement of Xanthomonas oryzae pv. oryzae in Southeast Asia Detected Using PCR-Based DNA Fingerprinting
}

\author{
M. L. C. George, M. Bustamam, W. T. Cruz, J. E. Leach, and R. J. Nelson
}

First and fifth authors: Division of Entomology and Plant Pathology, International Rice Research Institute, P.O. Box 933, Manila, Philippines; second author: Research Institute for Food Crops Biotechnology, Bogor, Indonesia; third author: Philippine Rice Research Institute, Muñoz, Nueva Ecija, Philippines; and fourth author: Department of Plant Pathology, Throckmorton Hall, Kansas State University, Manhattan 66506-5502.

Current address of R. J. Nelson: Centro International de la Papa (CIP), Apartado 1558, Lima 12, Peru.

Accepted for publication 13 November 1996.

\begin{abstract}
George, M. L. C., Bustamam, M., Cruz, W. T., Leach, J. E., and Nelson, R. J. 1997. Movement of Xanthomonas oryzae pv. oryzae in southeast Asia detected using PCR-based DNA fingerprinting. Phytopathology 87:302-309.

Two outwardly directed primers complementary to sequences in IS1112, a repetitive element isolated from Xanthomonas oryzae pv. oryzae, were used to fingerprint DNA from a set of 71 bacterial blight pathogen strains using polymerase chain reaction (PCR), PCR-based restriction analysis, and ligation-mediated PCR. To allow amplification of long DNA fragments, standard amplification conditions were altered

methods revealed useful polymorphisms among individual strains and allowed their genetic relationships to be efficiently deduced. Good correlation was found between the major clusters obtained by the three methods. The PCR method gave the most robust clusters and was most efficient in terms of speed, simplicity, and economy. Using PCR and restriction fragment length polymorphism to compare strains of the bacterial blight pathogen from Indonesia and the Philippines, we found that, whereas there is regional differentiation of the pathogen populations, the predominant strains in the pathogen collections from both countries are closely related. This indicates the occurrence of regional movement, perhaps as a consequence of germ plasm exchange.
\end{abstract} to increase the $\mathrm{pH}$, add dimethylsulfoxide, decrease denaturation time, and increase extension time. Bands ranging in size from $100 \mathrm{bp}$ to $7 \mathrm{~kb}$ and in number from 13 to 48 bands per strain were amplified. The three
Additional keyword: phylogenetic analysis.

Bacterial blight of rice, caused by the pathogen Xanthomonas oryzae pv. oryzae, is endemic in many parts of Asia. The primary means of disease control is through the use of resistant cultivars. Over time, however, virulent strains of the pathogen have overcome resistant cultivars (19). In the Philippines, for example, the widespread deployment of rice varieties carrying the $\mathrm{Xa}-4$ gene for resistance to bacterial blight led to a shift in the predominant pathogen race: from race 1 (avirulent on $\mathrm{Xa}-4$ ) to race 2 (virulent on $X a-4)(20)$. Based on DNA fingerprinting studies, this race shift was inferred to result from mutation and migration from a distant highland population, rather than from mutation(s) arising within the previously predominant pathogen population (21).

The movement of pathogens has important implications for the control of plant disease. If migration is far reaching, the development and deployment of resistant germ plasm would require knowledge about the structure and dynamics of distant, as well as local, populations of the pathogen. Thus, it is important to understand pathogen migration and how it influences population genetic structure and potential for disease. Several examples of pathogen migration have been documented, including intercontinental movement of Phytophthora infestans (10) and Puccinia graminis (5) and movement of Erysiphe graminis from continental Europe to England (4). In most cases, the arrival of immigrant genotypes has been associated with increased disease problems.

For the bacterial blight pathogen, geographic differentiation between populations in different agroecosystems was observed in the Philippines by Ardales et al. (2) from the analysis of over

Corresponding author: R. J. Nelson; E-mail address: r.nelson@ cgnet.com

Publication no. P-1997-0204-02R

C) 1997 The American Phytopathological Society
1,200 isolates sampled systematically along a $310-\mathrm{km}$ transect spanning indigenous rice-growing highlands and modern agroecosystems. A high degree of genetic differentiation among the sites was estimated, but, at the same time, some haplotypes were widely distributed. Within Asia, Adhikari et al. (1) analyzed 308 strains of the pathogen from seven rice-growing countries (China, India, Indonesia, Korea, Malaysia, Nepal, and the Philippines) and detected evidence suggesting both regional differentiation and pathogen migration between countries. They noted that many groups of similar strains were specific to one country, but that some groups of the pathogen were common to more than one country.

To understand the ecology of pathogens and their potential for change, various phenotypic characters, as well as molecular markers, have been used in studies of pathogen populations $(12,14,16,18)$. Several repetitive elements found in the bacterial blight pathogen have been used as probes in restriction fragment length polymorphism (RFLP) analysis $(13,15,21)$. However, for the large number of samples needed for ecological studies, a simpler and cheaper technology is required. The polymerase chain reaction (PCR) is increasingly becoming an important tool in population biology, because of its simplicity and potential to rapidly screen a large number of samples with a minimal amount of DNA. For example, REP-PCR, which is based on primers corresponding to repetitive extragenic palindromic (REP) (23), and enterobacterial repetitive intergenic consensus (ERIC) sequences (11) have been used to fingerprint Gram-negative soil bacteria and plant pathogenic bacteria and fungi $(7,8,17,24)$.

IS1112 is a relatively high copy number repetitive element isolated from X. oryzae pv. oryzae (15). When used as a probe, IS1112 detects genomic polymorphisms among isolates of the bacterial blight pathogen $(1,13,21)$ and also among isolates of $X$. 
oryzae pv. oryzicola, a closely related pathogen of rice (15). In their study of Philippine strains of $X$. oryzae pv. oryzae using four different repetitive elements (IS1112, IS1113, TNX6, and TNX7) and an avirulence gene as probes, Nelson et al. (21) found that the groupings formed on the basis of IS1112 and IS1113 were the most robust, showing the highest overall bootstrap values for the major groups of strains.

In this paper, we report the development and application of robust PCR-based fingerprinting methods for the bacterial blight pathogen $X$. oryzae pv. oryzae. We developed and assessed three PCR-based methods: PCR, PCR-based restriction analysis (PBRA), and ligation-mediated PCR (LMPCR) using primers hybridizing to the repetitive element IS1112. These methods were compared for their ability to detect variation and generate useful data for phenetic analysis. Further, we used PCR and RFLP to compare pathogen populations in the Philippines and Indonesia and to provide inferences about their diversity and relationships. In both countries, bacterial blight is an endemic disease and similar rice varieties are widely cultivated. We found that, while there is regional differentiation of the pathogen populations, the two countries also share a closely related group of the bacterial blight pathogen, indicating the occurrence of regional migration, perhaps as a consequence of germ plasm exchange.

\section{MATERIALS AND METHODS}

Bacterial strains and culture media. A set of $71 X$. oryzae pv. oryzae strains collected from the Philippines and maintained at the International Rice Research Institute (IRRI, Manila, Philippines) was used in evaluating three PCR-based methods of DNA fingerprinting. These strains were previously characterized with regard to their phylogeny and virulence $(13,20,21)$. DNA from Escherichia coli $\mathrm{DH} 5 \alpha, 20$ DNA samples from $X$. oryzae pv. oryzicola, five DNA samples from Pseudomonas sp., 28 DNA samples from the rice blast fungus Pyricularia grisea, and five DNA samples from rice Oryza sativa were also subjected to the PCR method.

In addition, three sets of $X$. oryzae pv. oryzae strains representing different haplotypes collected throughout the Philippines and Indonesia were analyzed together using the PCR and RFLP methods. These included a set $(n=29)$ of Philippine strains maintained at the IRRI and previously determined to represent the different RFLP-defined haplotypes observed in the Philippines (21). In separate studies, researchers in the Philippine and Indonesian national rice research programs conducted systematic and intensive sampling of the $X$. oryzae pv. oryzae populations in their respective countries. Among 286 Philippine isolates collected by X. Trung of the Philippine Rice Research Institute (PhilRice) from 1993 to 1994, 12 distinct haplotypes were detected (W. Cruz, unpublished data). Nineteen strains representing these haplotypes were kindly provided by PhilRice. Among 546 Indonesian isolates collected from 1974 to 1994 by researchers from the Research Institute for Food Crops Biotechnology (RIFCB), 18 haplotypes were detected (M. Bustamam, unpublished data). DNA samples of 19 representative strains were kindly provided by M. Yunus of RIFCB.

Isolation of genomic DNA. Genomic DNA of $X$. oryzae pv. oryzae strains were prepared from 5-ml nutrient broth (Difco Laboratories, Detroit) cultures grown overnight that were collected and then lysed in $650 \mu \mathrm{l}$ of extraction buffer (100 mM Tris, pH 8; $100 \mathrm{mM}$ EDTA; $250 \mathrm{mM} \mathrm{NaCl} ; 1 \%$ sodium dodecyl sulfate, wt/vol; and $1 \%$ polyvinylpyrrolidone, molecular weight $40,000, \mathrm{wt} / \mathrm{vol})$ at $65^{\circ} \mathrm{C}$ for $30 \mathrm{~min}$. Cellular proteins were precipitated with $100 \mu \mathrm{l}$ of potassium acetate $(3 \mathrm{M}$ potassium and 5 $\mathrm{M}$ acetate, $\mathrm{pH} 4.8$ ), and then DNA was precipitated using isopropanol. The DNA was dissolved in sterile distilled water and quantified using the DNA-specific dye Hoechst 33258 and a TKO-100 minifluorometer (Hoefer Scientific Instruments, San Francisco).
Oligonucleotide design and synthesis. The primer and linker sequences were designed based on the sequence of the repetitive element IS1112 (26) using the software PC/GENE (IntelliGenetics, Mountain View, CA). The two primers (JEL1 5'-CTCAGGTCAGGTCGCC-3' and JEL2 5'-GCTCTACAATCGTCCGC-3') were designed from each end of IS1112 in opposite orientation such that the $3^{\prime}$ ends were directed outwards from each element. The linker 5'-CTCAGGTCAGGTCGCC-3' 3'-GAGTCCAGTCCAGCGGCTAG-5' contained nonphosphorylated BamHI-compatible cohesive ends on its longer strand and was designed so that BamHI could not digest the ligated products, making the removal of the enzyme unnecessary prior to ligation. The shorter strand of the linker was identical to the primer JEL1 and served as a priming site distal to the repetitive element. The oligonucleotides were synthesized by Keystone Laboratories, Inc. (Menlo Park, CA).

PCR. Amplification was performed in a $25-\mu \mathrm{l}$ volume containing $0.5 \mu \mathrm{M}$ each of the two opposing primers, $20 \mathrm{ng}$ of genomic DNA, $185 \mu \mathrm{M}$ each of four dNTPs, and approximately $2.5 \mathrm{U}$ of Taq polymerase in a standard incubation buffer $(100 \mathrm{mM}$ Tris, $\mathrm{pH}$ $8.3 ; 500 \mathrm{mM} \mathrm{KCl} ; 1.5 \mathrm{mM} \mathrm{MgCl} 2$, and $0.01 \%$ gelatin, wt/vol) amended with $10 \%$ dimethylsulfoxide (vol/vol) and $7.5 \mu \mathrm{l}$ of $1 \mathrm{M}$ Tris ( $\mathrm{pH}$ 9.5) to promote the amplification of long DNA fragments (6). The reaction mixture was overlaid with one drop of mineral oil, initially denatured for $1 \mathrm{~min}$ at $94^{\circ} \mathrm{C}$, and then subjected to 30 cycles of PCR (10-s denaturation at $94^{\circ} \mathrm{C}, 1-\mathrm{min}$ annealing at $62^{\circ} \mathrm{C}$, and 10 -min extension at $65^{\circ} \mathrm{C}$ ) and a final extension for 15 min at $65^{\circ} \mathrm{C}$ using a DNA thermal cycler (Perkin-Elmer Cetus, Foster City, CA). PBRA was done by digesting $10 \mu \mathrm{l}$ of the amplified product with $5 \mathrm{U}$ of $\mathrm{BamHI}$ in a $20-\mu \mathrm{l}$ volume for at least $1 \mathrm{~h}$ at $37^{\circ} \mathrm{C}$.

LMPCR involves the generation of cohesive ends on restriction sites between repetitive elements, the ligation of a linker that serves as the opposite primer binding site distal to the repetitive element, and the amplification of sequences flanking the repetitive elements (22). The LMPCR method was designed to amplify the flanking sequences on both sides of the repetitive element IS1112, the fragments spanning one end of the element, and the nearest BamHI restriction site. Theoretically, this method would generate two fragments between two repetitive elements having at least one restriction site, in contrast to simple repetitive element-based PCR, which would generate one fragment spanning the whole intervening sequence (Fig. 1).

Briefly, genomic DNA was digested to completion with $10 \mathrm{U}$ of BamHI per microgram of DNA. Five $\mu$ l of digested DNA (100 ng) and $10 \mu \mathrm{l}$ of the linker $(50 \mathrm{pg} / \mu \mathrm{l})$ were mixed together, warmed to $45^{\circ} \mathrm{C}$ for $5 \mathrm{~min}$, and then chilled in an ice bath. Five $\mu$ of buffer

Repetitive element Restriction site

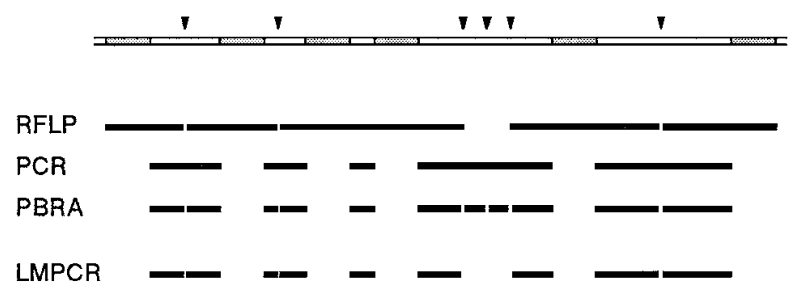

Fig. 1. Scheme for generating DNA fingerprints using an outwardly directed primer pair based on the sequence of IS1112, a dispersed repetitive element found in Xanthomonas oryzae pv. oryzae. The restriction fragment length polymorphism method detects sequences between two restriction sites that contain the repetitive element(s). Polymerase chain reaction (PCR) amplifies sequences between the repetitive elements, while PCR-based restriction analysis (PBRA) generates additional bands based on the presence of restriction sites $(B a m \mathrm{HI})$ within the amplified sequences. Ligation-mediated PCR (LMPCR) amplifies sequences between the repetitive element and a restriction site $($ Bam $\mathrm{HI})$ to which a linker is ligated. 

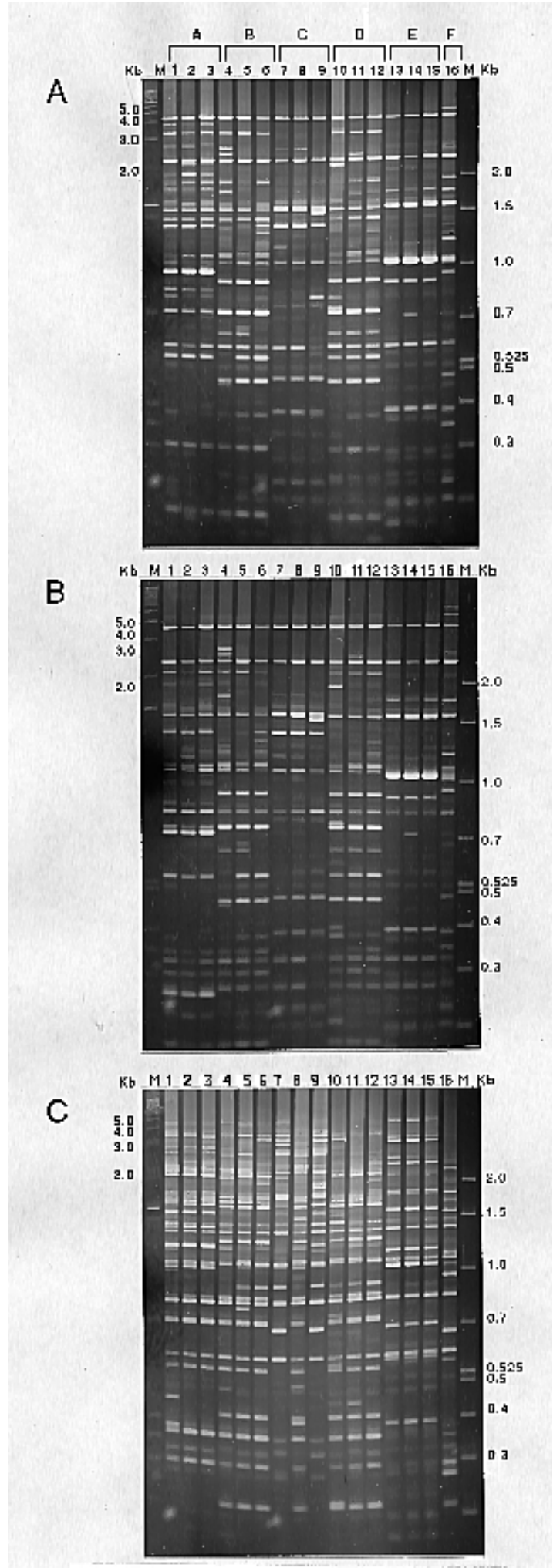

Fig. 2. IS1112-based polymerase chain reaction (PCR) fingerprint patterns from genomic DNA of Xanthomonas oryzae pv. oryzae isolates from the Philippines. Representative fingerprint patterns resulting from A, PCR; B, PCR-based restriction analysis (PBRA); and $\mathbf{C}$, ligation-mediated PCR (LMPCR) of isolates lane 1, PXO225; lane 2, PXO080; lane 3, PXO181; lane 4, PXO141; lane 5, PXO150; lane 6, PXO300; lane 7, PXO039; lane 8, PXO188; lane 9, PXO170; lane 10, PXO204; lane 11, PXO219; lane 12, PXO221; lane 13, PXO114; lane 14, PXO115; lane 15, PXO117; and lane 16, PXO035 are shown. The letters represent the lineage designation of the strains based on restriction fragment length polymorphism analysis (20). The DNA molecular size markers are on the lane labeled $\mathrm{M}$ on the left $(1-\mathrm{kb}$ ladder, Life Technologies, Inc., Gaithersburg, MD) and right (BioMarker EXT, Bioventures, TN). mixture containing $2 \mu \mathrm{l}$ of $10 \times$ ligation buffer (Boehringer Mannheim [Far East], Singapore) and $1 \mathrm{U}$ of T4 DNA ligase (Boehringer Mannheim [Far East]) were added, and the resulting mixture was incubated at $15^{\circ} \mathrm{C}$ for at least $4 \mathrm{~h}$. One microliter of the ligated mixture was used as template in the PCR reaction. A negative control without template DNA was included in all experiments. Each experiment was done at least twice.

To visualize the DNA fingerprints, $10 \mu \mathrm{l}$ of the PCR products or $20 \mu \mathrm{l}$ of the digested PCR products were loaded in a gel containing $0.5 \%$ agarose and $0.75 \%$ Synergel (Diversified Biotech, Newton Center, MA) and $0.5 \times$ Tris-borate buffer $(89 \mathrm{mM}$ Tris, $\mathrm{pH} 7.8 ; 89 \mathrm{mM}$ boric acid; and $2 \mathrm{mM}$ EDTA). Gels were run for 6 $\mathrm{h}$ at $125 \mathrm{~V}$, stained with ethidium bromide, and then photographed using Polaroid Type 55 film (Polaroid Corp., Cambridge, MA). Prints were enlarged to $20 \times 25 \mathrm{~cm}$ to facilitate the scoring of bands. All bands were scored regardless of intensity. For composite PCR-based restriction analysis, the undigested and digested PCR products from each DNA sample were loaded separately, but side by side, in adjacent lanes. A single PBRA fingerprint was scored by combining the new bands resulting from digestion with the original bands of the undigested PCR product.

PCR of bacterial exudate. To amplify DNA from bacteria leached from infected leaves, 2-cm-long leaf fragments containing the advancing tip of lesions were cut crosswise into smaller pieces with flame-sterilized scissors and then soaked in $400 \mu \mathrm{l}$ of sterile distilled water for at least $1 \mathrm{~h}$. The leaf pieces were discarded, and the bacterial cells were concentrated by centrifugation $(10,000 \times g$ for $2 \mathrm{~min}$ ). Most of the water was discarded, leaving about $25 \mu \mathrm{l}$ in which the cells were resuspended. The cells were lysed in 200 $\mu \mathrm{l}$ of $70 \%$ ethanol and then spun for $10 \mathrm{~s}$ to pellet the cell debris. The supernatant was transferred to a new tube and spun for $5 \mathrm{~min}$ to precipitate the DNA. The DNA was dissolved in $10 \mu \mathrm{l}$ of sterile water, and $5 \mathrm{ml}$ served as template in the simple PCR method. To check the consistency of the fingerprint patterns, DNA from the isolates used for inoculation were used as positive controls.

RFLP analysis. Approximately $2 \mu \mathrm{g}$ of genomic DNA was digested overnight with $20 \mathrm{U}$ of EcoRI (Boehringer Mannheim [Far East]) at $37^{\circ} \mathrm{C}$. Digested fragments were separated by electrophoresis in $0.7 \%$ agarose gel containing $0.5 \times$ Tris-borate buffer for 16 $\mathrm{h}$ at $40 \mathrm{~V}$, and transferred to Hybond $\mathrm{N}^{+}$membrane according to the manufacturer's recommendations (Amersham [Far East], Hong Kong).

The probe IS1113, consisting of a 1-kb transposable element isolated from $X$. oryzae pv. oryzae cloned in pBluescript (21), was propagated in E. coli DH5 $\alpha$. The plasmid was isolated from overnight cultures by the alkaline lysis procedure (3), digested with EcoRI at $37^{\circ} \mathrm{C}$ for $1 \mathrm{~h}$, and labeled by random priming overnight at $37^{\circ} \mathrm{C}$ with digoxigenin-labeled dUTP (Boehringer Mannheim [Far East]). The probe was hybridized to blots according to manufacturer's instructions using high stringency conditions $(5 \times$ SSPE [ $1 \times \mathrm{SSPE}$ is $0.18 \mathrm{M} \mathrm{NaCl}, 10 \mathrm{mM} \mathrm{NaPO}_{4}$, and $1 \mathrm{mM}$ EDTA, pH 7.7] at $65^{\circ} \mathrm{C}$ ). Hybridized bands were detected directly on the blot by the chromogenic method using 5-bromo-4-chloro-3-indolyl phosphate and nitroblue tetrazolium as substrates. RFLP analysis was done twice.

Numerical analysis of PCR data. The banding pattern of each strain was coded in binary form, 1 representing the presence and 0 the absence of each band. Dendrograms were generated within the SAHN program of NTSYS-pc (Exeter Software, Setauket, NY) using the unweighted pair-group method with arithmetic averages (UPGMA) method. Similarity matrices were calculated using Dice's coefficient with the SIMQUAL program. Correlation analysis by the MXCOMP program was done for pairs of similarity matrices to compare the relationships among strains inferred using different DNA fingerprinting methods.

The robustness of each dendrogram was assessed by bootstrap analysis (9) with the WinBoot program $(21,25)$ using 2,000 repeated samplings with replacement. The bootstrap values, re- 
flecting the frequency with which each group is formed in repeated cycles of dendrogram construction, were used as a measure of the relative stability of the clusters of strains.

\section{RESULTS}

DNA fingerprinting of $X$. oryzae pv. oryzae strains using three PCR-based methods. A preliminary study of the PCR and LMPCR methods was done using outwardly directed primers based on the sequence of IS1113, an insertion element used as an RFLP probe in previous studies $(2,21)$. However, only a few bands were amplified, from one to two bands in PCR and one to seven in LMPCR (data not shown). We then tried a primer pair complementary to sequences of IS1112, a higher copy number element. As the IS1112 primers gave fingerprints with sufficient bands, they were used to fingerprint a set of $71 X$. oryzae pv. oryzae strains by PCR, PBRA, and LMPCR (Fig. 1). To allow amplification of long DNA fragments, we amended standard amplification conditions by increasing the buffer $\mathrm{pH}$, adding dimethylsulfoxide, decreasing the denaturation time, and increasing the extension time (6). Under these conditions, fragments as long as $7 \mathrm{~kb}$ were amplified (Fig. 2), in contrast to about $4 \mathrm{~kb}$ without the amendments (data not shown).

Variable-length intervening sequences between the elements in the genome of $X$. oryzae pv. oryzae strains were amplified using the PCR-based methods (Fig. 2). All three methods produced bands that were common to the 71 strains examined and also bands that were either specific to a group of strains belonging to the same RFLP-defined lineage or unique to one or a few related strains (Fig. 2A, B, and C). Polymorphic bands were also generated using DNA from other bacteria such as $X$. oryzae pv. oryzicola, Pseudomonas sp., and E. coli (data not shown). DNA from X. oryzae pv. oryzicola, which also contains IS1112 (13), and Pseudomonas sp. produced band patterns comparable in complex-

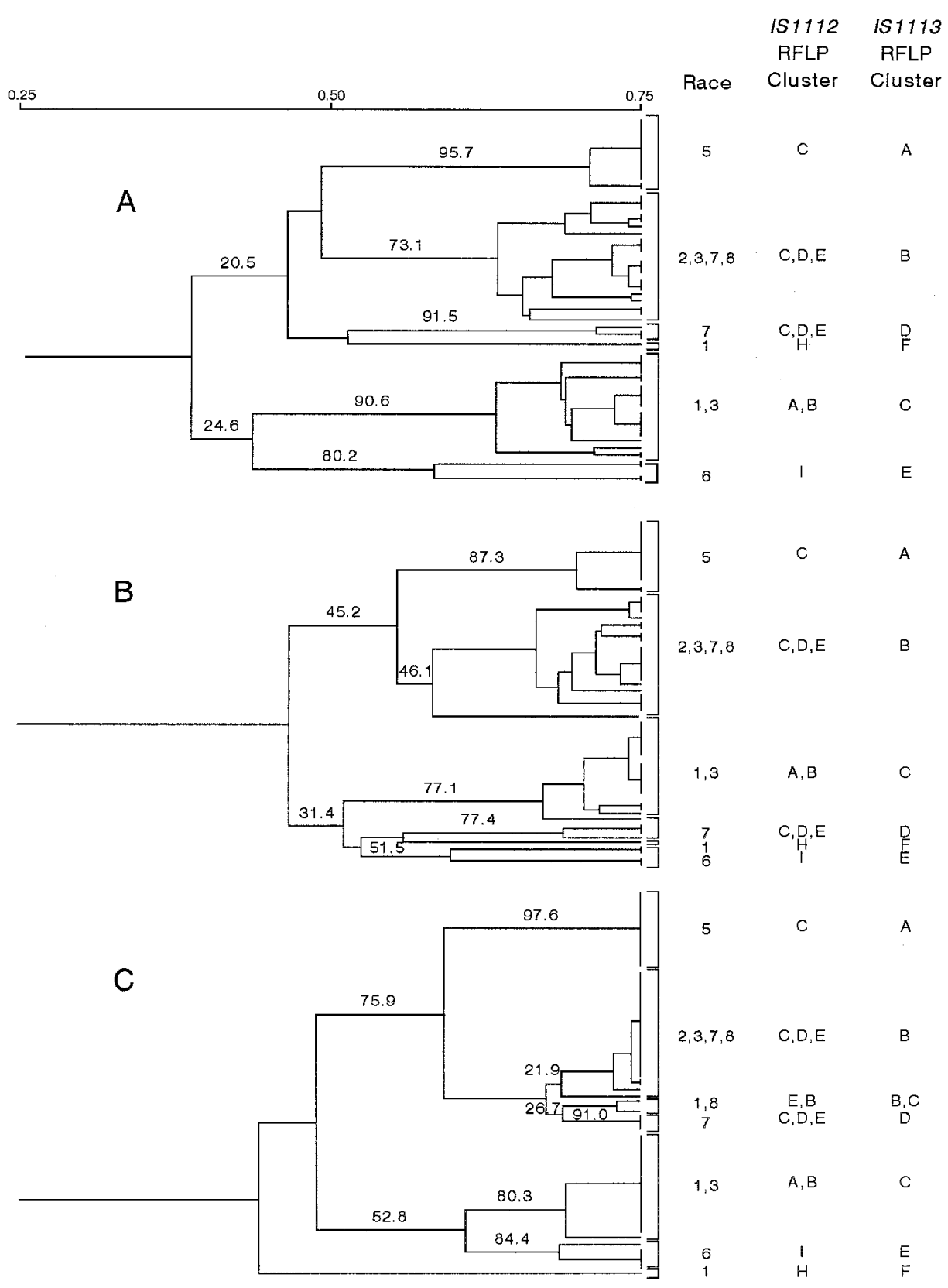

Fig. 3. Dendrograms constructed from A, polymerase chain reaction (PCR); B, PCR-based restriction analysis; and C, ligation-mediated PCR fingerprint data from 71 Xanthomonas oryzae pv. oryzae strains from the Philippines. Numbers represent the race designations of strains associated with each grouping, and letters represent the lineage designation of the strains based on restriction fragment length polymorphism analysis using IS1112 as a probe (21). The bootstrap values, noted as numbers on the main branches of the dendrograms, indicate the percentage of the 2,000 iterations in which the major groups of strains were formed. 
ity with those of $X$. oryzae pv. oryzae, while fewer bands were amplified using E. coli DNA as template. PCR products also were amplified using template DNA from the blast fungus Pyricularia grisea. However, in contrast to the band patterns obtained from bacteria, the bands obtained from fungal DNA of 28 Pyricularia grisea strains from eight lineages were fewer and generally monomorphic, and their amplification required a lower annealing temperature $\left(52^{\circ} \mathrm{C}\right)$. No bands were amplified using DNA from rice.

Bands ranging in size from $100 \mathrm{bp}$ to $7 \mathrm{~kb}$ and in number from 13 to 35 bands per strain were amplified by PCR (Fig. 2A). Restriction of the amplified fragments with BamHI resulted in little or no net increase in the number of bands detected (Fig. 2B). The additional fragments produced by restriction were offset by the disappearance of some of the digested bands and the inability to detect the resulting smaller fragments in the gel. To increase the number of bands scored per isolate, a composite dataset was analyzed, consisting of the undigested amplified products and the bands newly formed by digestion. This increased the number of bands scored from an average of 26 per isolate in PCR to 35 in the composite fingerprint. An average of 36 bands was generated by the LMPCR method (Fig. 2C). There were 112, 118, and 116 band positions scored in PCR, composite PBRA, and LMPCR, respectively. Although there were more bands generated by LMPCR per strain, more bands were scored in composite PBRA, because a wider range of fragment sizes was included.
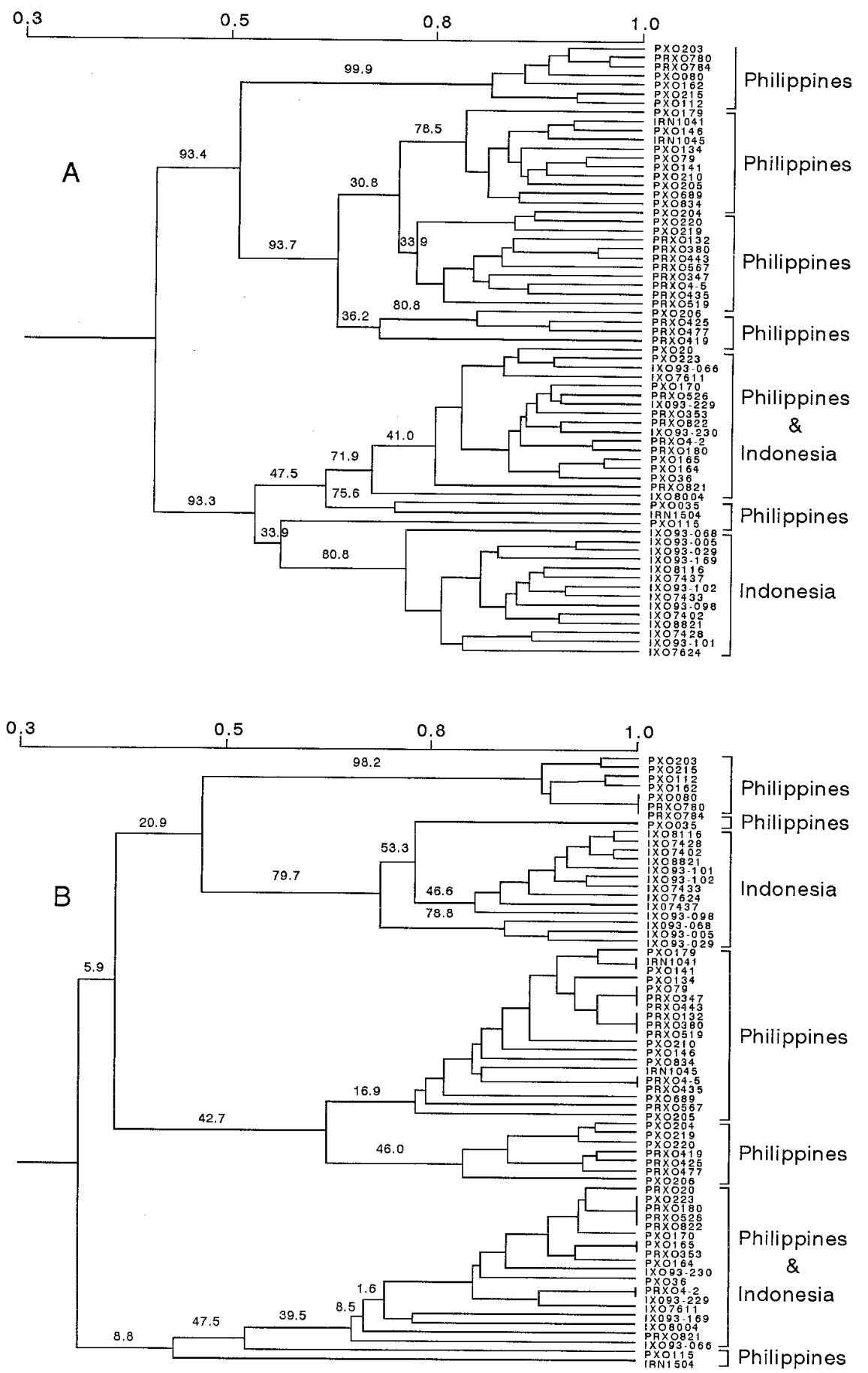

Fig. 4. Dendrograms constructed from A, polymerase chain reaction (PCR) and B, restriction fragment length polymorphism (RFLP) fingerprint data from 67 Xanthomonas oryzae pv. oryzae strains representing the different IS1113 RFLP haplotypes isolated from the Philippines and Indonesia. The strains from the Philippines and Indonesia that clustered together were identical for both PCR and RFLP. The bootstrap values, noted as numbers on the main branches of the dendrograms, indicate the percentage of the 2,000 iterations in which the major groups of strains were formed. 
Numerical analysis. Dendrograms constructed with UPGMA using the datasets obtained with the PCR-based DNA fingerprinting methods are presented in Figure 3. The major clusters defined by the three methods were similar. These groupings more closely corresponded to their RFLP-defined groupings based on IS1113 than to those groupings based on IS1112. In general, the major PCR groupings corresponded to distinct IS1113-defined RFLP lineages. In contrast, some of the major PCR groupings included several IS1112-defined RFLP lineages. The closer correspondence between the IS1112 PCR and IS1113 RFLP groupings may be related to differences in the RFLP fingerprint patterns obtained with the IS1112 and IS1113. Because IS1112 RFLP fingerprints have numerous bands (21), some information may be lost when high molecular weight bands are not clearly resolved. In contrast, the fewer IS1113-based RFLP bands are all scorable, as are the IS1112-based PCR bands. Correlation analysis was performed to quantify the relationship between strains inferred using the different DNA fingerprinting methods (Table 1). The similarity matrices of the PCR-based methods were highly correlated, with those derived from the PCR and composite PBRA $(r=0.95)$ having the highest correlation. The three IS1112-based PCR methods had a high correlation with the IS1113-based RFLP method, but a lower correlation with the IS1112-based RFLP method (Table 1). Using this set of $71 X$. oryzae pv. oryzae strains, the same correlation value ( $r=0.57$ ) was obtained between the similarity matrices of IS1112 and IS1113 RFLP methods as that derived previously using a larger set of 155 strains (21).

Bootstrap analyses showed that most of the major clusters formed by the three PCR-based methods were moderately robust, having bootstrap values ranging from 73 to $96 \%$ using PCR (Fig. 3A), 46 to $87 \%$ using composite PBRA (Fig. 3A), and 22 to $98 \%$ using LMPCR (Fig. 3C). As found by Nelson et al. (21), there was no clear-cut correspondence between these major groupings and the race of the isolates, except for races 5 and 6 , which showed consistent groupings regardless of the DNA fingerprinting method used (Fig. 3).

PCR of bacterial exudate. Consistent amplification was obtained using DNA from bacteria leached from infected leaves, and the fingerprint patterns were similar to those obtained using pure DNA from the isolates used to inoculate the plants. Fingerprints also were obtained using DNA from bacteria leached from lesions collected directly from the field (data not shown).

Comparison of Philippine and Indonesian strains of $X$. oryzae pv. oryzae. The PCR method was used to compare the bacterial blight pathogen populations of the Philippines and Indonesia using strains selected from much larger collections resulting from systematic sampling of the pathogen in the two countries. Figure 4 shows the dendrograms constructed using PCR and RFLP fingerprint data from $67 X$. oryzae pv. oryzae strains representing the different IS1113 RFLP haplotypes detected in the two countries thus far. All the strains were associated at the $42 \%$ similarity level using PCR (Fig. 4A) and at the 35\% level using

TABLE 1. Matrix correlations for similarity matrices obtained with different DNA fingerprinting methods for analysis of 71 strains of Xanthomonas oryzae pv. oryzae

\begin{tabular}{lcccc}
\hline & \multicolumn{4}{c}{ Correlation $(r)$ with: } \\
\cline { 2 - 5 } $\begin{array}{l}\text { IS1112-based DNA } \\
\text { fingerprinting method }\end{array}$ & $\begin{array}{l}\text { IS1112 } \\
\text { PBRA }^{\mathrm{a}}\end{array}$ & $\begin{array}{c}\text { IS1112 } \\
\text { LMPCR }^{\mathrm{b}}\end{array}$ & $\begin{array}{c}\text { IS1112 } \\
\text { RFLP }^{\mathrm{c}}\end{array}$ & $\begin{array}{c}\text { IS1113 } \\
\text { RFLP }^{\mathrm{c}}\end{array}$ \\
\hline PCR & 0.95 & 0.79 & 0.41 & 0.78 \\
PBRA $^{\mathrm{a}}$ & & 0.78 & 0.37 & 0.75 \\
LMPCR $^{\mathrm{b}}$ & & & 0.45 & 0.83 \\
RFLP $^{\mathrm{C}}$ & & & & 0.57 \\
\hline
\end{tabular}

a Polymerase chain reaction (PCR)-based restriction analysis.

${ }^{\mathrm{b}}$ Ligation-mediated PCR.

c Restriction fragment length polymorphism based on binary data used by Nelson et al. (21)
RFLP (Fig. 4B). Five major clusters were formed by strains collected only from the Philippines, one cluster by those collected only from Indonesia, and one cluster by those collected from both countries. The group formed by strains from both countries consisted of 12 strains from the Philippines and five from Indonesia that shared very similar, although not identical, PCR fingerprints (Fig. 4A).

Results of RFLP analysis of the Indonesian and Philippine strains using IS1113 as a probe were consistent with the results of the PCR (Figs. 4B and 5). Groupings derived using the RFLP data corresponded with those produced by PCR (Fig. 4B), with a matrix correlation value of $r=0.81$. Bootstrap values for the major PCR clusters ranged from 72 to $100 \%$, while those of the RFLP clusters ranged from 48 to $98 \%$. Seventeen strains (five from Indonesia and 12 from the Philippines) clustered together based on both PCR and RFLP analyses. Of these 17 strains, one strain from Indonesia and another from the Philippines had identical RFLP fingerprints. Those haplotypes that formed the common cluster are
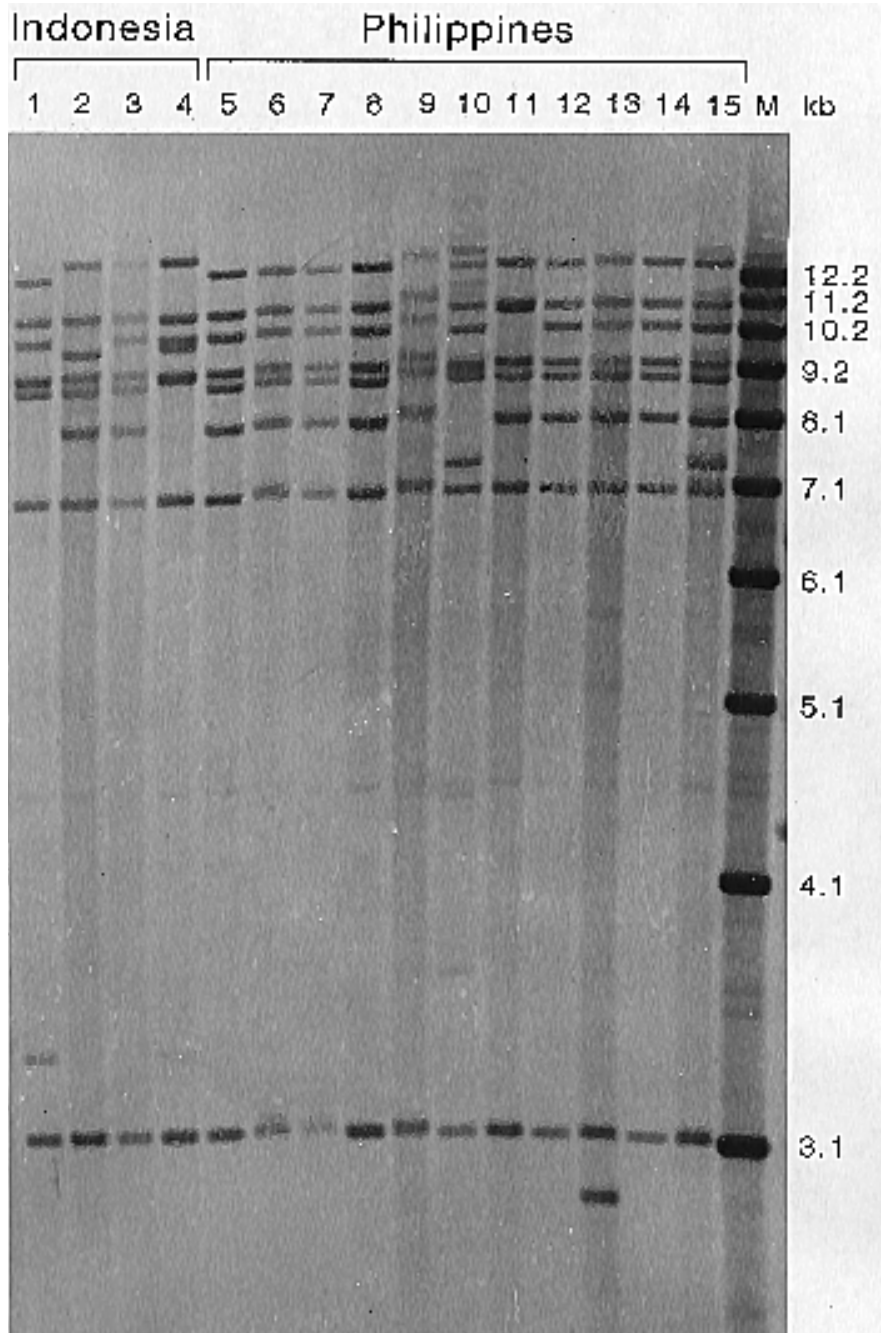

Fig. 5. IS1113-based DNA hybridization patterns of some Xanthomonas oryzae pv. oryzae strains from the Philippines and Indonesia that share a common lineage. Lane 1, IXO93-230; lane 2, IXO76-11; lane 3, IXO93-229; lane 4, IXO93-66; lane 5, PRXO353; lane 6, PRXO822; lane 7, PRXO526; lane 8, PRXO180; lane 9, PRXO4-2; lane 10, PXO36; lane 11, PXO164; lane 12, PXO165; lane 13, PXO170; lane 14, PXO223; and lane 15, PRXO20. Strains with the prefixes IXO, PRXO, and PXO are from the collections of the Central Research Institute for Food Crops (Indonesia), the Philippine Rice Research Institute (Philippines), and the International Rice Research Institute (Philippines), respectively. The DNA molecular size markers are on the lane labeled $\mathrm{M}$ on the right (1-kb ladder; Life Technologies, Inc., Gaithersburg, MD). 
predominant in the two countries, making up $98 \%$ in the Indonesian collection (M. Bustamam, unpublished data) and $86 \%$ in the Philippine collection (W. Cruz, unpublished data).

\section{DISCUSSION}

Using PCR- and RFLP-based markers to compare strains of the bacterial blight pathogen from Indonesia and the Philippines, we found that, while some groups of strains were specific to each country, some strains from the two countries were very similar. In a preliminary study of 125 strains of the pathogen collected in West Java, Indonesia, one lineage predominated, making up 75\% of the collection (M. Bustamam, unpublished data). Of this lineage, one type was similar to the predominant IS1113 RFLP haplotype observed for race 3 in the Philippines. More recent studies on the bacterial blight populations in the Philippines (2; W. Cruz, unpublished data; C. Vera Cruz, personal communication) and Indonesia (M. Bustamam, unpublished data) showed that the same haplotypes are widespread in the two countries. We interpret this finding as evidence for movement of the pathogen between the two countries, probably resulting from the transmission of the strains through contaminated germ plasm. The prevalence of these strains in the two countries could be due to the popularity of IR64, a high yielding variety that was bred at the IRRI in the Philippines. The widespread cultivation of this variety, which contains the $\mathrm{Xa}-4$ gene for resistance to bacterial blight, may have imposed strong selection for the introduced virulence in Indonesia and caused displacement of the indigenous populations. Alternatively, the strains could have originated from Indonesia and moved to the Philippines.

Adhikari et al. (1) noted clustering of strains from different countries when they evaluated strains from collections in China, India, Indonesia, Korea, Malaysia, Nepal, and the Philippines, suggesting the movement of the pathogen within Asia. In their study using IS1112 and the avirulence gene (avrXa10) as RFLP probes, very tight clusters were formed by strains from China and Indonesia, from Indonesia and Malaysia, and from the Philippines alone. However, strains common to the Philippines and Indonesia were not detected. In this study, a cluster of closely related strains shared by the two countries was detected by using a selected set of strains that represents the diversity of the local pathogen populations. Such a difference in findings is largely due to differences in sampling. The study of Adhikari et al. (1) was done earlier, before the pathogen collection at the RIFCB in Indonesia was fully developed and characterized by DNA fingerprinting. Thus, there was no knowledge at that time on the nature and distribution of pathogen lineages in the country.

It has been possible to detect pathogen migration directly with the use of molecular markers, and the polymerase chain reaction makes the study of pathogen populations less cumbersome and more economical than with RFLP-based DNA fingerprinting. In this study, we developed and assessed three PCR-based methods to fingerprint the bacterial blight pathogen. DNA fingerprint patterns reflecting variation in the number and distribution of the repetitive element IS1112 in the genome were produced. Existing variation was detectable within the limitations of polymerase extension, which was about $7 \mathrm{~kb}$.

Overall, the PCR method was most efficient in terms of simplicity, speed, and economy. Although PBRA and LMPCR generated more bands per strain in the fingerprints (Table 1), thus yielding more discriminating power, the clusters were not as robust as with plain PCR, and the extra information provided by the additional bands did not justify the time and cost required by the two methods. There is also a technical trade-off, since scoring of individual bands can be difficult when they are more numerous and more ambiguous when there is a greater chance of comigration of nonidentical bands. The convenience of the PCR method makes it highly suitable for analyzing large numbers of samples, allowing for greater efficiency in the study of pathogen populations. The utility of the PCR is further enhanced, because fingerprinting could be done directly using DNA from bacteria leached from lesions. Because neither isolation nor cultivation of the pathogen are required, PCR of DNA from lesion exudates reduces the time required to fingerprint the bacterial blight pathogen from 6 to 2 days. Techniques such as these make it possible to monitor future movement of the pathogen and to assess the effects of resistance deployment on pathogen population structure.

The evidence presented here of the breaching of ocean barriers has significant implications for rice breeding and deployment programs that seek to use resistance to $X$. oryzae pv. oryzae to control bacterial blight disease. Our evidence for the movement of strains between populations separated by geographic, as well as political, boundaries suggests the need for a shared solution involving regional cooperation in breeding, evaluation, and deployment of resistance. Because the pathogen populations can migrate throughout a wider area, regional management of resistance may be necessary. Furthermore, given the international scope of rice breeding programs, the potential for seedborne transmission suggests that strict quarantine measures should be followed when there is exchange of germ plasm. Unfortunately, there is no reliable and sensitive method for detecting and diagnosing seedborne $X$. oryzae pv. oryzae. Repetitive element-based PCR, because of its speed and sensitivity, holds the promise of making a significant practical impact in plant quarantine programs. The identification of sequences unique to the pathogen and to its races, combined with the use of the PCR, could be useful for routine seed testing.

\section{ACKNOWLEDGMENTS}

This work was supported by Technical Assistance 5510 from the Asian Development Bank to the International Rice Research Institute within the collaborative framework of the Asian Rice Biotechnology Network. We thank M. Yunus, X. Trung, R. Scott, M. Villamayor, A. Monroy, E. Ardales, M. Baraoidan, C. Vera Cruz, and W. Apolinario for their assistance in various aspects of this work.

\section{LITERATURE CITED}

1. Adhikari, T. B., Vera Cruz, C. M., Zhang, Q., Nelson, R. J., Skinner, D. Z., Mew, T. W., and Leach, J. E. 1995. Genetic diversity of Xanthomonas oryzae pv. oryzae in Asia. Appl. Environ. Microbiol. 61:966-971.

2. Ardales, E. Y., Leung, H., Vera Cruz, C. M., Mew, T. W., Leach, J. E., and Nelson, R. J. 1996. Hierarchical analysis of spatial variation of the rice bacterial blight pathogen across diverse agroecosystems in the Philippines. Phytopathology 86:241-252.

3. Birnboim, H. C., and Doly, J. 1979. A rapid alkaline extraction procedure for screening recombinant plasmid DNA. Nucleic Acids Res. 7:1513-1523.

4. Brown, J. K. M., Jessop, A. C., and Rezanoor, H. N. 1991. Genetic uniformity in barley and its powdery mildew pathogen. Proc. R. Soc. Lond. Ser. B 246:83-90.

5. Burdon, J. J., Marshall, D. R., Luig, N. H., and Gow, D. J. S. 1982. Isozyme studies on the origin and evolution of Puccinia graminis $\mathrm{f}$. $\mathrm{sp}$. tritici in Australia. Aust. J. Biol. Sci. 35:231-238.

6. Cheng, S., Fockler, C., Barnes, W. M., and Higuchi, R. 1994. Effective amplification of long targets from cloned inserts and human genomic DNA. Proc. Natl. Acad. Sci. U.S.A. 91:5695-5699.

7. de Bruijn, F. J. 1992. Use of repetitive (repetitive extragenic palindromic and enterobacterial intergeneric consensus) sequences and the polymerase chain reaction to fingerprint the genomes of Rhizobium meliloti isolates and other soil bacteria. Appl. Environ. Microbiol. 58:2180-2187.

8. Edel, V., Steinberg, C., Avelange, I., Laguerre, G., and Alabouvette, C. 1995. Comparison of three molecular methods for the characterization of Fusarium oxysporum strains. Phytopathology 85:579-585.

9. Felsenstein, J. 1985. Confidence limits on phylogenies: An approach using the bootstrap. Evolution 39:783-791.

10. Fry, W. E., Goodwin, S. B., Matuszak, J. M., Spielman, L. J., Milgroom, M. G., and Drenth, A. 1992. Population genetics and intercontinental migrations of Phytophthora infestans. Annu. Rev. Phytopathol. 30:107129.

11. Hulton, C. S. J., Higgins, C. F., and Sharp, P. M. 1991. ERIC sequences: A novel family of repetitive elements in the genomes of Escherichia 
coli, Salmonella typhimurium and other enterobacteria. Mol. Microbiol. 5:825-834.

12. Leach, J. E., Leung, H., Nelson, R. J., and Mew, T. W. 1995. Population biology of Xanthomonas oryzae pv. oryzae and approaches to its control. Curr. Opin. Biotechnol. 6:298-304.

13. Leach, J. E., Rhoads, M. L., Vera Cruz, C. M., White, F. F., Mew, T. W., and Leung, H. 1992. Assessment of genetic diversity and population structure of Xanthomonas oryzae pv. oryzae with a repetitive element. Appl. Environ. Microbiol. 58:2188-2195.

14. Leach, J. E., and White, F. F. 1991. Molecular probes for disease diagnosis and monitoring. Pages 281-307 in: Rice Biotechnology. G. S. Khush and G. H. Toenniessen, eds. CAB International, Wallingford, United Kingdom, and International Rice Research Institute, Manila Philippines.

15. Leach, J. E., White, F. F., Rhoads, M. L., and Leung, H. 1990. A repetitive DNA sequence differentiates Xanthomonas campestris pv. oryzae from other pathovars of $X$. campestris. Mol. Plant-Microbe Interact. 3:238-246.

16. Leung, H., Nelson, R. J., and Leach, J. E. 1993. Population structure of plant pathogenic fungi and bacteria. Adv. Plant Pathol. 10:157-205.

17. Louws, F. J., Fulbright, D. W., Stephens, C. T., and de Bruijn, F. J. 1994. Specific genomic fingerprints of phytopathogenic Xanthomonas and Pseudomonas pathovars and strains generated with repetitive sequences and PCR. Appl. Environ. Microbiol. 60:2286-2295.

18. McDonald, B. A., and McDermott, J. M. 1993. Population genetics of plant pathogenic fungi. BioScience 43:311-319.

19. Mew, T. W. 1987. Current status and future prospects of research on bacterial blight of rice. Annu. Rev. Phytopathol. 24:359-382.

20. Mew, T. W., Vera Cruz, C. M., and Medalla, E. S. 1992. Changes in race frequency of Xanthomonas oryzae pv. oryzae in response to rice cultivars planted in the Philippines. Plant Dis. 76:1029-1032.

21. Nelson, R. J., Baraoidan, M., Vera Cruz, C. M., Yap, I. V., Leach, J. E., Mew, T. W., and Leung, H. 1994. Relationship between phylogeny and pathotype for the bacterial blight pathogen of rice. Appl. Environ. Microbiol. 60:3275-3283.

22. Palittapongarnpim, P., Chomyc, S., Fanning, A., and Kunimoto, D. 1993. DNA fingerprinting of Mycobacterium tuberculosis isolates by ligationmediated polymerase chain reaction. Nucleic Acids Res. 21:761-762.

23. Stern, M. J., Ames, G. F. L., Smith, N. H., Robinson, E. C., and Higgins, C. F. 1984. Repetitive extragenic palindromic sequences, a major component of the bacterial genome. Cell 37:1015-1026.

24. Vera Cruz, C. M., Ardales, E. Y., Skinner, D. Z., Talag, J., Nelson, R. J., Louws, F. J., Leung, H., Mew, T. W., and Leach, J. E. 1996. Measurement of haplotypic variation in Xanthomonas oryzae pv. oryzae within a single field by rep-PCR and RFLP analyses. Phytopathology $86: 1352-1359$.

25. Yap, I., and Nelson, R. J. 1996. WinBoot: A program for performing bootstrap analysis of binary data to determine the confidence limits of UPGMA-based dendrograms. IRRI Discussion Paper Series 14. International Rice Research Institute, Manila, Philippines.

26. Yun, C. H. 1991. Molecular characterization of a repetitive element of Xanthomonas oryzae pv. oryzae. Ph.D. thesis. Kansas State University, Manhattan. 